\title{
Antimicrobial activity of the reef sponge Amphimedon viridis from the Red Sea: evidence for selective toxicity
}

\author{
Dovi Kelman ${ }^{1,2, *}$, Yoel Kashman ${ }^{3}$, Eugene Rosenberg ${ }^{4}$, Micha Ilan$^{1}$, Ilan Ifrach ${ }^{1}$, \\ Yossi Loya ${ }^{1,2}$
}

\begin{abstract}
${ }^{1}$ Department of Zoology, George S. Wise Faculty of Life Sciences, ${ }^{2}$ National Center for High Throughput Screening (HTS) of Novel Bioactive Compounds, ${ }^{3}$ School of Chemistry, and ${ }^{4}$ Department of Molecular Microbiology and Biotechnology, George S. Wise Faculty of Life Sciences, Tel Aviv University, Ramat Aviv, Tel Aviv 69978, Israel
\end{abstract}

\begin{abstract}
Living benthic marine organisms such as sponges and corals are frequently colonized by bacteria that may be pathogenic to them. One of the means by which they are able to combat microbial attack is by chemical defense. We tested the activity of crude organic extracts of 11 dominant Red Sea reef sponges against a panel of bacteria isolated from their natural environment. Amphimedon viridis (Keller) exhibited the highest antimicrobial activity. Bioassay-directed fractionation resulted in the isolation of an active fraction that contained a purified mixture of halitoxin and amphitoxin, which are highly bioactive pyridinium alkaloids. These compounds showed selective activity against specific bacteria rather than being of a broad spectrum. They were highly active against 8 strains of bacteria isolated from the seawater surrounding these sponges, whereas 6 different bacterial strains associated with the sponge $A$. viridis were resistant to these compounds. This selective toxicity may be important in enabling certain bacteria to live in close association with their sponge host while it maintains a chemical defense against microbial pathogenesis.
\end{abstract}

KEY WORDS: Antimicrobial activity $\cdot$ Chemical defense $\cdot$ Sponges $\cdot$ Marine bacteria $\cdot$ Amphimedon Halitoxin $\cdot$ Secondary metabolites $\cdot$ Red Sea

\section{INTRODUCTION}

Living benthic marine organisms such as sponges and corals are frequently colonized by bacteria (Mitchell \& Chet 1975, Rublee et al. 1980, Ducklow 1990, Walls et al. 1993). Some of these bacteria can be pathogenic, and may initiate diseases such as black band disease (Antonius 1985, Edmunds 1991), tissue necrosis (Hodgson 1990), or even bleaching in the case of the Mediterranean scleractinian coral Oculina patagonica (Kushmaro et al. 1996, 1997). Since microorganisms are ubiquitous in the marine environment (Austin 1988) and especially on the surface of benthic inverte-

*E-mail: kelmand@post.tau.ac.il brates, these organisms need to resist microbial colonization by potential pathogens. One method of combating microbial attack is by chemical defense.

Sponges offer a rich source of unique and diverse secondary metabolites (Faulkner 2000, and references therein). Many of these compounds have potent pharmacological activities, including anti-tumor, antifungal, anti-viral, and anti-bacterial properties (Wallace 1997). Several antibiotics have been isolated from marine sponges, e.g., plakortin from Plakortis halichondroides (Higgs \& Faulkner 1978), and manoalide from Luffariella variabilis (De Silva \& Scheuer 1980). However, these antibiotics, and others isolated from marine sponges, were identified as active against human pathogens or against marine bacteria that have no obvious ecological relevance to the producing 
organism. Several recent reports on antimicrobial activity of sponges and corals have examined the activity of secondary metabolites against ecologically relevant bacteria in order to elucidate their function in the chemical mediation of interactions between marine sessile invertebrates and bacteria (Becerro et al. 1994, Wahl et al. 1994, Slattery et al. 1995, Jensen et al. 1996, Kelman et al. 1998, Maximilien et al. 1998, Newbold et al. 1999). The controlled diffusion of antibiotic agents in the living tissues of sponges may increase their efficiency (Bergquist \& Bedford 1978), and may thereby provide a better defense against microbial infections (Amade et al. 1987). Furthermore, these metabolites may also be used to regulate symbiotic bacterial populations known to associate with sponges (Bergquist 1978).

In this study, we tested the activity of crude organic extracts of 11 dominant Red Sea reef sponges against a panel of bacteria isolated from their natural environment. Preliminary experiments indicated that Amphimedon viridis (Keller) possessed the highest antimicrobial activity. Consequently, the objectives of this study were to isolate its antibiotic and test whether it possesses broad-spectrum activity or selective activity against specific bacteria.

\section{MATERIALS AND METHODS}

Collection. Eleven species of marine sponges were collected using SCUBA from the coral reef of Eilat (northern Red Sea) between October 1997 and April 1999 at depths of 1 to $30 \mathrm{~m}$. Since this coral reef extends for only a few kilometers, we were not able to distinguish between possible asexually produced clones. Therefore, for every species, the extract was prepared from a pool of at least 3 replicate samples. Each sponge sample was immediately frozen after collection and maintained at $-20^{\circ} \mathrm{C}$ prior to extraction.

Samples for bacterial isolation were collected from the same location. Tissue samples $(1 \times 1 \mathrm{~cm}$ in area, $\mathrm{n}=3)$ of the sponge Amphimedon viridis and the corals Stylophora pistillata, and healthy and necrotic Parerythropodium fulvum fulvum were selected from colonies with no epiphytic algae and transferred to $50 \mathrm{ml}$ sterile tubes filled with sterile (autoclaved) seawater (SSW). The sponge and coral samples were washed 4 times prior to bacterial isolation with SSW to remove unattached or loosely attached bacteria from their surface. Seawater samples were collected in situ by opening $50 \mathrm{ml}$ sterile tubes near sponge or coral colonies. Sediment samples were collected adjacent to sponge or coral colonies, and placed in similar tubes. All samples were kept at $4^{\circ} \mathrm{C}$ and transferred immediately to the laboratory in Tel-Aviv for bacterial isolation.
Bacterial isolation and characterization. The bacteria used in the antimicrobial assays (Table 1) were isolated using standard serial dilution and plating techniques on Marine Agar (18 g Difco Marine Broth [MB], $9 \mathrm{~g} \mathrm{NaCl}$ and $18 \mathrm{~g}$ Difco Agar, per $1 \mathrm{l}$ of deionized water) or TCBS Agar (45 g Difco TCBS Agar, $9 \mathrm{~g} \mathrm{MB}$, $4.5 \mathrm{~g} \mathrm{NaCl}, 9 \mathrm{~g}$ Difco Agar, per $1 \mathrm{l}$ of deionized water), and incubated at $25^{\circ} \mathrm{C}$, corresponding to the ambient seawater temperature.

Gram reaction was determined by conventional staining techniques and by the $\mathrm{KOH}$ method (see Buck 1982 for details). Cell morphology was determined using light and transmission electron microscopy (TEM). The presence of flagella was determined by TEM. Bacteria were observed by TEM using the negative staining method. Bacteria were adhered to a carbon-coated grid and stained with $1 \%$ uranyl acetate for $1 \mathrm{~min}$ and observed under a JEOL GEM-1200EX TEM.

The strains used in the antimicrobial assays were tentatively identified by 22 biochemical tests (oxidase, indole production, reduction of nitrates to nitrites, reduction of nitrates to nitrogen, acidification of glucose, arginine dihydrolyase, urease, esculine hydrolysis, protease, $\beta$-galactosidase, and assimilation of glucose, arabinose, mannose, mannitol, $\mathrm{N}$-acetyl-glucosamine, maltose, gluconate, caprate, adipate, malate, citrate, phenyl-acetate) using api-20 NE (micromethod tests for the identification of non-enteric Gram-negative bacteria; bioMérieux sa, Marcy-l'Etoile, France). The standard api-20NE method was used, with the media adjusted to $3 \% \mathrm{NaCl}$. In addition, BIOLOG's GN2 and GP2 MicroPlates ${ }^{\mathrm{TM}}$ (Biolog Inc., Hayward, CA, USA) were used. These test panels provide a standardized micromethod utilizing 95 different carbon sources for the identification of a broad range of Gramnegative and Gram-positive bacteria, respectively. The standard BIOLOG procedure was used, with the inoculating fluid adjusted to $2.5 \% \mathrm{NaCl}, 0.8 \% \mathrm{MgCl}_{2}$, $0.05 \% \mathrm{KCl}$ and $0.15 \%$ Carrageenan type II (Sigma) for marine bacteria. The identification results were confirmed using Bergey's Manual ${ }^{\circledast}$ of determinative bacteriology (Holt et al. 1994).

Sensitivity to antibiotics $(10 \mu \mathrm{g}$ penicillin-G, $10 \mu \mathrm{g}$ ampicillin, $30 \mu \mathrm{g}$ kanamycin, $30 \mu \mathrm{g}$ tetracycline and $15 \mu \mathrm{g}$ erythromycin, each applied to a paper disc) was determined after incubation for $24 \mathrm{~h}$ at $25^{\circ} \mathrm{C}$ on Marine Agar.

Extraction and isolation. The sponge samples were allowed to thaw, and were then cut into small pieces and placed in a $1000 \mathrm{ml}$ graduated cylinder containing a known amount of seawater in order to measure their volume. The samples, drained of excess water, were extracted in a 1:1 dichloromethane:methanol (DCM: $\mathrm{MeOH}$ ) solution for $24 \mathrm{~h}$ at room temperature. The 
organic extracts were filtered, and the solvent was removed by rotary evaporation under vacuum at $30^{\circ} \mathrm{C}$. The dried extracts were weighed and kept at $-20^{\circ} \mathrm{C}$ for further use.

Preliminary investigations indicated that Amphimedon viridis (Keller) possessed the highest antimicrobial activity among the Red Sea sponges investigated. Therefore, a large amount of sponge tissue (83 $\mathrm{g}$ dry weight) was extracted first with 1:1 ethyl-acetate: $\mathrm{MeOH}$ and then with $\mathrm{MeOH}$. The solvents were then evaporated to dryness under reduced pressure with a rotary evaporator, and assayed for antimicrobial activity against the test strain ST-1 (see Table 1). Since the $\mathrm{MeOH}$ extract was found to be active, it was used for further bioassay-directed fractionation in order to isolate the active substance. The $\mathrm{MeOH}$ extract after evaporation was partitioned between n-butanol and water, the solvents were evaporated and the fractions assayed for antimicrobial activity. Subsequent purification of constituent compounds from the active n-butanol phase employed size-exclusion chromatography using Sephadex LH-20, with MeOH elution. Resulting fractions were analyzed using thin-layer chromatography (TLC) developed with $25 \%$ ammonium hydroxide-ethanol 1:4 (v/v) and stained with ninhydrin. The active fractions were analyzed by a Bruker ARX 500 NMR (nuclear magnetic resonance) spectrometer. The purified fractions were also subjected to antimicrobial assays. Comparison of the NMR data with the literature enabled structural elucidation of the active metabolites.

Antimicrobial assays. Assays were performed as previously described (Kelman et al. 1998). In brief, inocula of overnight cultures (approximately $10^{7}$ cells $\mathrm{ml}^{-1}$ ) of each bacterial strain were streaked onto the surface of Marine Agar plates. The crude sponge extract dissolved in ethanol was adjusted to the same volumetric concentration as was present in the sponge tissue. Then, $30 \mu \mathrm{l}$ of the extract was pipetted onto a $6 \mathrm{~mm}$ sterile paper disc, the solvent was allowed to evaporate, and the disc was placed on the surface of the inoculated agar. The test plates were incubated for $24 \mathrm{~h}$ at $25^{\circ} \mathrm{C}$; solvent controls were performed in each case. Areas of inhibited bacterial growth were observed as clear halos (zones) around the discs. Antibacterial activity was measured as diameter of zone of inhibition, excluding the paper disc diameter.

Minimum inhibitory concentration (MIC) was measured by determining the smallest amount of extract or pure compound needed to inhibit the growth of a test bacterium. This was done using 96-well plates and performed on a GENESIS Workstation automation system (Tecan AG, Hombrechtikon, Switzerland). The assay plates were filled with liquid broth medium (MB) containing a series of concentrations of extract or pure compounds (ranging from 1 to $250 \mu \mathrm{g} \mathrm{ml}^{-1}$ ), test bacteria and solvent controls. After overnight and $48 \mathrm{~h}$ incubation periods at $25^{\circ} \mathrm{C}$, the turbidity in each well was measured at $620 \mathrm{~nm}$ using SPECTRAFluor Plus (Tecan Austria GmbH, Grödig, Austria).

Scanning electron microscopy (SEM). Observations of sponge surfaces for possible detection of epibiotic bacteria were performed using SEM. Several pieces of sponge samples were preserved in a solution containing $2.5 \%$ glutaraldehyde and $1 \%$ formalin in SSW and kept at $4{ }^{\circ} \mathrm{C}$. The samples were washed 3 times with phosphate buffered saline (PBS) at room temperature, dehydrated through a graded series of ethyl alcohols and critically point dried. The samples were coated with gold and examined with a JEOL JSM-840A SEM.

Statistical analysis. Differences between MICs of purified compounds and crude extracts of Amphimedon viridis against $A$. viridis-associated and seawater bacteria were analyzed using non-parametric Friedman analysis of variance (ANOVA) tests (Sokal \& Rohlf 1995)

\section{RESULTS}

Six strains of bacteria were isolated from samples of the reef sponge Amphimedon viridis, 8 from the surrounding seawater, and 2 from adjacent sediment, as well as bacteria associated with the stony coral Stylophora pistillata, and healthy and necrotic soft coral Parerythropodium fulvum fulvum. Their characteristics and partial identification are summarized in Table 1. The bacteria were Gram-negative, except for strains RSW-1, RSW-3, RSW-13 and RSW-16 isolated from seawater, which were Gram-positive. Several strains isolated from seawater, sediment or corals were tentatively identified by the biochemical micromethods BIOLOG or api-20. In contrast, the 6 Gram-negative strains isolated from the reef sponge $A$. viridis had no match in the bacterial databases of these identification kits. The strains isolated in this study exhibited variable sensitivity to different commercial antibiotics (results not shown), further demonstrating that they are different bacterial strains. Strains that had similar antibiotic sensitivity (e.g., AV-3 and AV-4) were different according to their colony morphology and color on $\mathrm{MB}$ and TCBS agar.

Preliminary antimicrobial assays performed with organic extracts of 11 dominant Red Sea reef sponges against various Red Sea marine bacteria (Table 2) revealed considerable variability in antimicrobial activity. Eight out of 11 (73\%) of the sponge species inhibited at least 1 bacterial isolate. Among them, Amphimedon viridis exhibited the highest antimicrobial activity. Observation of surfaces of $A$. viridis by SEM failed to reveal any bacteria (Fig. 1). 
Table 1. Description of isolated bacteria used in the antimicrobial assays. nd: not determined

\begin{tabular}{|c|c|c|c|c|c|c|}
\hline $\begin{array}{l}\text { Bacterial } \\
\text { strain }\end{array}$ & Source & $\begin{array}{l}\text { Gram } \\
\text { reaction }\end{array}$ & $\begin{array}{l}\text { Bacterial } \\
\text { shape }\end{array}$ & $\begin{array}{l}\text { Presence of } \\
\text { flagella }\end{array}$ & Species & $\begin{array}{l}\text { Method of } \\
\text { identification }^{\mathrm{a}}\end{array}$ \\
\hline RSW-2 & Seawater & - & Coccobacilli & - & Chryseomonas sp. & $\begin{array}{l}\text { api-20 (no match } \\
\text { with BIOLOG) }\end{array}$ \\
\hline RSW-3 & Seawater & + & Rod & - & Unidentified & $\begin{array}{l}\text { No match with } \\
\text { BIOLOG }^{\text {b }}\end{array}$ \\
\hline RSW-14 & Seawater & - & Rod & nd & Vibrio sp. & BIOLOG \\
\hline RSW-1 & Seawater & + & Rod & nd & Unidentified & - \\
\hline ST-1 & $\begin{array}{l}\text { Stylophora pistillata } \\
\text { (stony coral) }\end{array}$ & - & Rod & + & Vibrio sp. & BIOLOG \\
\hline \multirow[t]{2}{*}{ P-1 } & Necrotic & & & & & \\
\hline & $\begin{array}{l}\text { Parerythropodium fulvum } \\
\text { fulvum (soft coral) }\end{array}$ & $n$ & Rod & nd & Vibrio sp. & api-20 \\
\hline D-1 & $\begin{array}{l}\text { Parerythropodium fulvum } \\
\text { fulvum }\end{array}$ & $n$ & Rod & nd & Pseudomonas sp. & api-20 \\
\hline S-15 & Sediment & - & Rod & nd & Vibrio alginolyticus & BIOLOG \\
\hline S-13 & Sediment & - & nd & nd & Unidentified & - \\
\hline RSW-16 & Seawater & + & Rod & + & Unidentified & $\begin{array}{l}\text { No match with } \\
\text { BIOLOG }^{\text {b }}\end{array}$ \\
\hline RSW-13 & Seawater & + & Cocci & - & Unidentified & $\begin{array}{l}\text { No match with } \\
\text { BIOLOG }^{\text {b }}\end{array}$ \\
\hline RSW-17 & Seawater & - & Rod & + & Vibrio metschnikovii & BIOLOG \\
\hline RSW-18 & Seawater & - & Rod & + & Aeromonas sp. & BIOLOG \\
\hline AV-1 & $\begin{array}{l}\text { Amphimedon viridis } \\
\text { (reef sponge) }\end{array}$ & - & Coccobacilli & + & Unidentified & $\begin{array}{l}\text { No match with } \\
\text { BIOLOG or api-20 }\end{array}$ \\
\hline AV-2 & Amphimedon viridis & - & Rod & + & Unidentified & $\begin{array}{l}\text { No match with } \\
\text { BIOLOG or api-20 }\end{array}$ \\
\hline AV-3 & Amphimedon viridis & - & Rod & + & Unidentified & $\begin{array}{l}\text { No match with } \\
\text { BIOLOG or api-20 }\end{array}$ \\
\hline $\mathrm{AV}-4$ & Amphimedon viridis & - & Rod & + & Unidentified & $\begin{array}{l}\text { No match with } \\
\text { BIOLOG or api-20 }\end{array}$ \\
\hline AV-5 & Amphimedon viridis & - & Rod & + & Unidentified & $\begin{array}{l}\text { No match with } \\
\text { BIOLOG or api-20 }\end{array}$ \\
\hline AV-6 & Amphimedon viridis & - & Rod & - & Unidentified & $\begin{array}{l}\text { No match with } \\
\text { BIOLOG or api-20 }\end{array}$ \\
\hline
\end{tabular}

Table 2. Antimicrobial activity of extracts of 11 dominant Red Sea reef sponges, applied at natural concentrations, against various Red Sea marine bacteria. Size of inhibition zones is expressed as:,$+ 0-2 \mathrm{~mm}_{i}++, 2-4 \mathrm{~mm}_{i}+++, 4-6 \mathrm{~mm}_{i}++++6-8 \mathrm{~mm} ;-, \mathrm{no}^{+}$ inhibition; nd, not determined

\begin{tabular}{|c|c|c|c|c|c|c|c|c|}
\hline \multirow{2}{*}{ Sponge } & \multicolumn{8}{|c|}{ Test microorganism } \\
\hline & RSW-2 & RSW $-3^{a}$ & RSW-14 & ST-1 & P-1 & D-1 & S-15 & S-13 \\
\hline Amphimedon viridis & +++ & ++++ & + & ++++ & +++ & +++ & - & + \\
\hline Callyspongia siphonella & + & - & - & + & - & - & - & - \\
\hline Callyspongia sp. & + & nd & - & - & - & - & - & - \\
\hline Petrosia sp. & - & nd & - & - & - & - & - & - \\
\hline Epipolasis sp. & ++ & ++ & - & + & - & - & - & - \\
\hline Suberites clavatus & + & - & - & ++ & - & - & ++ & - \\
\hline Theonella swinhoei & + & nd & - & - & - & - & - & - \\
\hline Grayella cyatophora & - & - & - & - & - & - & - & - \\
\hline Biemna erhenbergi & + & - & - & - & - & - & - & - \\
\hline Diacarnus erythraenus & - & ++ & - & +++ & - & - & - & - \\
\hline Negombata magnifica & - & - & - & - & - & - & - & - \\
\hline
\end{tabular}




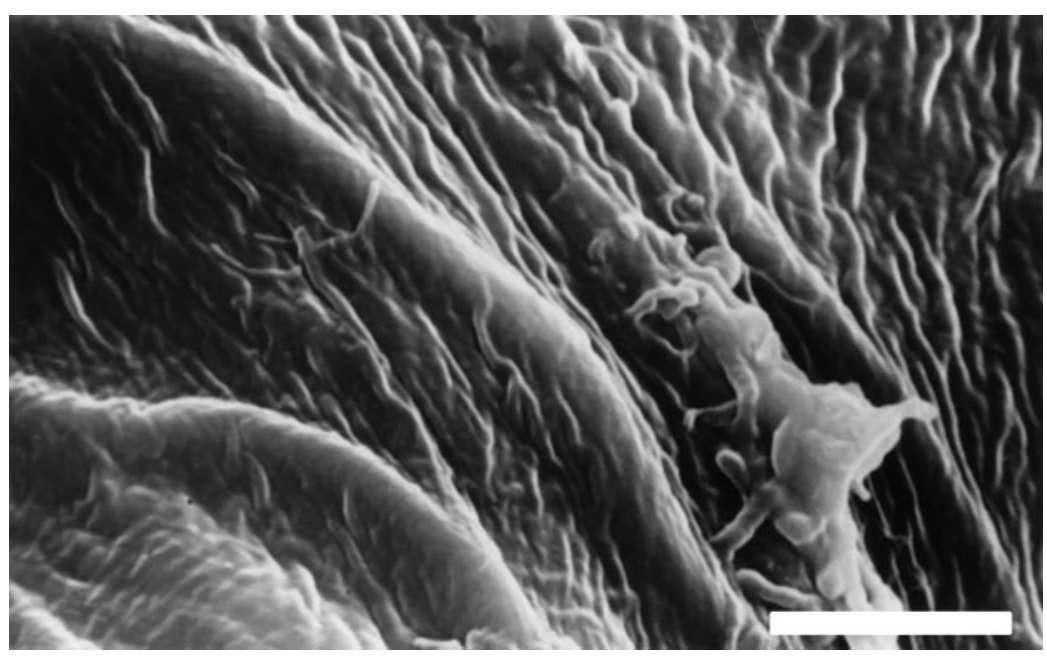

Fig. 1. Amphimedon viridis surface. SEM micrograph of a typical surface virtually free of epibiotic bacteria. Scale bar $=5 \mu \mathrm{m}$ inhibited at a MIC of $125 \mu \mathrm{ml}^{-1}$ of purified amphitoxin/halitoxin mixture and $63 \mu \mathrm{g} \mathrm{ml} \mathrm{m}^{-1}$ of crude extracts of A. viridis. In contrast, purified amphitoxin/halitoxin mixture and crude extracts of $A$. viridis inhibited the growth of 8 out of 8 seawater bacteria at MICs ranging from 4 to $250 \mu \mathrm{g} \mathrm{ml} \mathrm{m}^{-1}$. The 8 seawater bacteria consisted of an equal number of Gram-negative and Gram-positive strains. The differences in MICs of amphitoxin/halitoxin mixture against $A$. viridis-associated bacteria and seawater bacteria were significant $(\mathrm{p}<0.05)$. The selected commercial antibiotics exhibited variable MICs against $A$. viridis-associated and seawater bacteria (Table 3 ).

\section{DISCUSSION}

Bioassay-directed fractionation of the active butanol
partition of the crude extract of Amphimedon viridis resulted in the isolation of an active fraction containing an inseparable mixture of 2 closely related toxin homologues. These metabolites were identified as a mixture of amphitoxin and halitoxin (Fig. 2) by NMR spectroscopy and comparison with data reported in the literature (Schmitz et al. 1978, Albrizio et al. 1995, Berlinck et al. 1996). The metabolites gave the characteristic ${ }^{1} \mathrm{H}-\mathrm{NMR}$ signals $\left(500 \mathrm{MHz}, \mathrm{DMSO}-d_{6}\right)$ of a mixture of amphitoxin/halitoxin at 9.19, 9.06, 8.48, 8.41, 8.09, 5.57, 5.33, 4.62, 3.65, $2.94,2.78,2.13,1.97,1.63,1.28$ and $0.83 \mathrm{ppm}$; and ${ }^{13} \mathrm{C}-\mathrm{NMR}$ signals at 145.0, 143.9, 143.0, 142.2, 141.7, 127.9, $127.7,127.5,125.2,60.5,31.6$ and $30.7 \mathrm{ppm}$. Amphitoxin differs from halitoxin in that it has an additional carbon-carbon double bond in the alkyl chain linking the pyridinium rings. The estimated volumetric concentration of the amphitoxin/halitoxin mixture in tissues of $A$. viridis was ca $6.2 \mathrm{mg} \mathrm{ml}^{-1}$ (assuming 100\% recovery).

The MICs of purified amphitoxin/ halitoxin mixture and crude extracts of Amphimedon viridis, as well as selected commercial antibiotics against $A$. viridis-associated and seawater bacteria are presented in Table 3 . Five of the 6 A. viridis-associated bacteria were not inhibited by $250 \mu \mathrm{g} \mathrm{ml}^{-1}$ of purified amphitoxin/halitoxin mixture and crude extracts of $A$. viridis. Strain AV-2 was
The ecological role of sponge secondary metabolites in antimicrobial defense against co-occurring and potentially pathogenic marine bacteria is unclear. Moreover, their role in regulating symbiotic relationships between bacteria and their sponge hosts is also obscure. In the current study we have shown that the reef

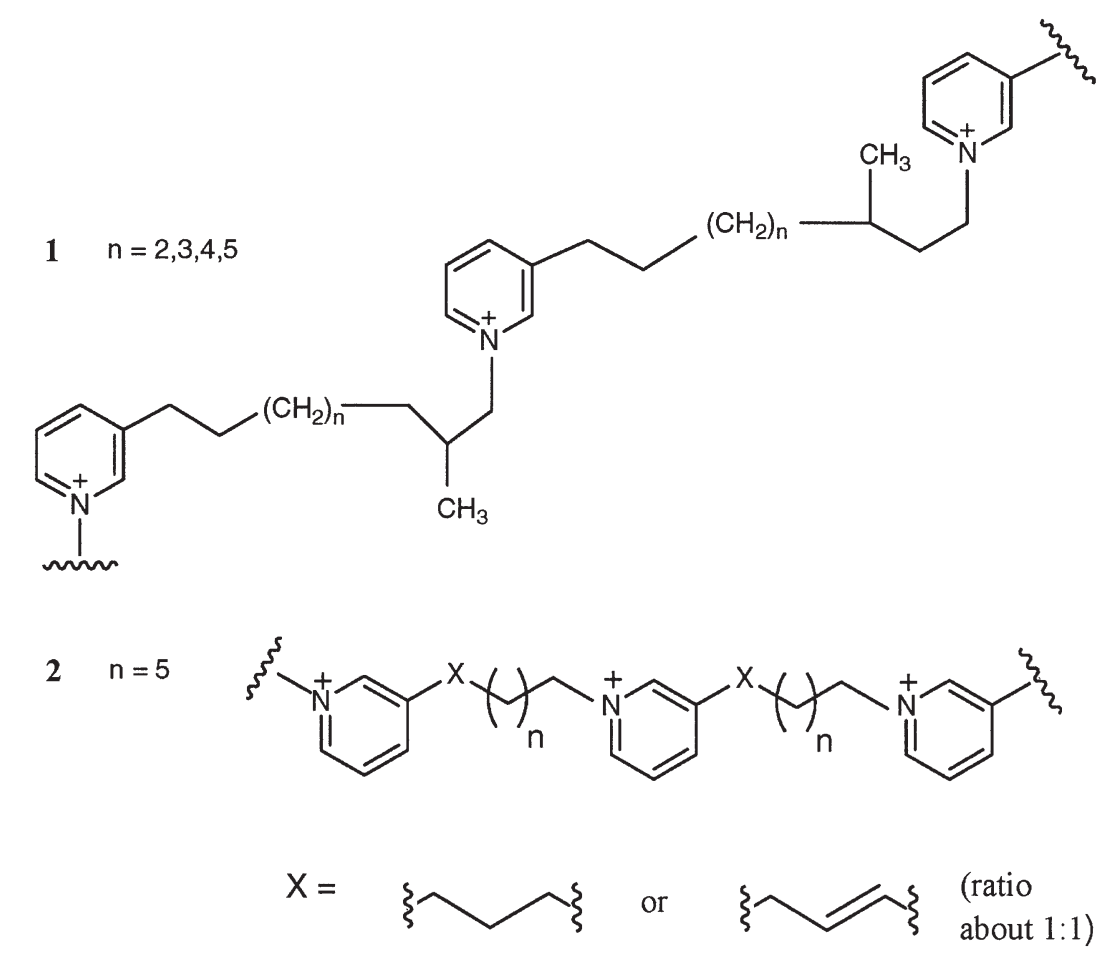

Fig. 2. Chemical structure of (1) halitoxin and (2) amphitoxin, the antimicrobial compounds present in the tissues of Amphimedon viridis 
Table 3. Minimum inhibitory concentrations $\left(\mu \mathrm{g} \mathrm{m}^{-1}\right)$ of amphitoxin/halitoxin mixture, crude extract of Amphimedon viridis and selected commercial antibiotics against growth of bacterial isolates from $A$. viridis and surrounding seawater. Poly-B = Polymixin B, Pen-G = Penicilin- $\mathrm{G}, \mathrm{Chl}=$ Chloramphenicol, $\mathrm{Nal}=$ Nalidixic acid, Strep $=$ Streptomycin, Tet $=$ Tetracycline, nd $=$ not determined

\begin{tabular}{|c|c|c|c|c|c|c|c|c|c|}
\hline Source & Isolate & $\begin{array}{c}\text { Crude } \\
\text { A. viridis }\end{array}$ & $\begin{array}{l}\text { Amphitoxin/ } \\
\text { halitoxin }\end{array}$ & Poly-B & Pen-G & $\mathrm{Chl}$ & $\mathrm{Nal}$ & Strep & Tet \\
\hline \multirow[t]{6}{*}{ A. viridis } & AV-1 & $>250$ & $>250$ & $>250$ & 1 & 2 & 16 & 31 & 2 \\
\hline & AV-2 & 63 & 125 & $>250$ & 63 & 2 & 16 & 31 & 8 \\
\hline & AV-3 & $>250$ & $>250$ & $>250$ & 1 & 2 & 16 & 63 & 2 \\
\hline & AV-4 & $>250$ & $>250$ & $>250$ & 1 & 1 & 31 & 31 & 2 \\
\hline & AV-5 & $>250$ & $>250$ & $>250$ & $>250$ & 2 & 16 & 31 & 8 \\
\hline & AV-6 & $>250$ & $>250$ & $>250$ & 1 & 2 & 16 & 31 & 4 \\
\hline \multirow[t]{8}{*}{ Seawater } & RSW-2 & 31 & 31 & 1 & 1 & 4 & $>125$ & 8 & 2 \\
\hline & RSW-3 & 31 & 31 & 250 & 1 & 8 & $>125$ & 16 & 8 \\
\hline & RSW-16 & 31 & 31 & 1 & 1 & 31 & 63 & 16 & 8 \\
\hline & RSW-13 & 31 & 31 & 8 & 1 & 4 & $>125$ & 16 & 63 \\
\hline & RSW-17 & 125 & 250 & 2 & 1 & 4 & 1 & 16 & 8 \\
\hline & RSW-18 & 250 & 250 & 4 & 63 & 4 & 16 & 16 & 8 \\
\hline & RSW-14 & 125 & 8 & 4 & 4 & 8 & nd & 63 & nd \\
\hline & RSW-1 & 31 & 4 & 125 & 8 & 31 & nd & 63 & nd \\
\hline
\end{tabular}

sponge Amphimedon viridis from the Red Sea possesses potent antibacterial activity. The activity was found to be due to a mixture of the antibiotics amphitoxin and halitoxin, which are complex pyridinium alkaloids. In previous studies, it was shown that halitoxin exhibits general cytotoxicity and was toxic to mice and sea urchin eggs, as well as possessing hemolytic and neurotoxic activity (Berlinck et al. 1996), and amphitoxin deterred the feeding of a generalist predatory fish in laboratory experiments (Albrizio et al. 1995). However, in the present study these highly bioactive pyridinium alkaloids showed selective activity to specific bacteria rather than being of a broad spectrum. The amphitoxin/halitoxin mixture isolated from $A$. viridis was highly active against 8 strains of bacteria isolated from the seawater surrounding these sponges, whereas 6 strains associated with the sponge were resistant to these compounds. This selective toxicity may be important in enabling certain bacteria to live in close association with their sponge host while it maintains a chemical defense against microbial pathogenesis.

The extracts and purified compounds that were tested for antimicrobial activity in the present study were tested at concentrations volumetrically equivalent to those found in the sponge tissues (whole-tissue concentrations). The importance of using ecologically realistic concentrations of secondary metabolites in chemical ecological studies was emphasized by Hay (1996), as well as by others (e.g., Schmitt et al. 1995, Jensen et al. 1996, Kelman et al. 1998, Maximilien et al. 1998, Dworjanyn et al. 1999). It is reasonable to assume that volumetric concentration of an extract is applicable when testing the activity against predators, such as reef fishes, which potentially damage the tested organism by consuming a relatively large volume of tissue; however, when studying the effects of secondary metabolites from marine benthic invertebrates against marine bacteria, it is not possible to estimate the concentrations that are potentially experienced by the microbes in nature. Therefore, we initially tested the Red Sea sponge extracts with whole-tissue concentration that overestimates natural concentrations for screening purposes. Under these conditions, an extract that was found to be non active is unlikely to be antimicrobial in nature. However, when we further investigated the antimicrobial effects of secondary metabolites of the reef sponge Amphimedon viridis and more specifically with its antibiotics halitoxin and amphitoxin, we sought the MICs, since we consider that these concentrations more effectively estimate the conditions experienced by microbes in nature.

Investigation of antimicrobial effects of secondary metabolites with disc-diffusion assays using agar media is limited, due to the variable diffusion rates of compounds in agar (Jenkins et al. 1998). This is particularly significant when testing a cationic high molecular weight antibiotic. Moreover, the simulation of natural concentrations on a volumetric basis, as described by Kim (1994), assumes that the extracts are equally distributed throughout the volume of the organism being tested. In corals, algae and in some sponges it is reasonable to assume that higher concentrations of bioactive compounds accumulate on their surfaces, thus providing greater defense against bacterial colonization. However, since sponges pass large volumes of water through their tissues (Bergquist 1978), which contain potentially harmful bacteria, as well as encountering them on their external surfaces, it may be advantageous for sponges to distribute their antimicrobials throughout their tissues. Several studies provided evidence for the localization of natural products within the tissues of sponges (e.g., Bewley et al. 1996, Uriz et al. 1996). Further investigations on the localization of antibiotics in tissues of marine sponges are therefore warranted. In the current study, the MIC assays were performed in liquid media, which ensures a uniform concentration of antibiotic and increases interaction between the antimicrobial agents and the tested microorganisms. In our view, such assay conditions better simulate the conditions experienced by microbes in nature. 
The bacterial strains isolated in this study were tentatively identified by morphological and biochemical tests. Several of these strains, especially those isolated from the reef sponge Amphimedon viridis, had no match in the bacterial databases of the identification kits used in the current study. This is not surprising as these databases are limited in the number of identified marine bacteria. However, for the purposes of the current study the biochemical identification was sufficient to show that the test microorganisms differed from one another. Additional bacterial identifications, especially utilizing molecular techniques, are required in order to learn more about the nature of the associated bacteria. By using molecular techniques, such as fluorescence in situ hybridization (FISH) and denatured gradient gel electrophoresis (DGGE), we could further investigate the localization and relative concentrations of these microbes in comparison to other unculturable bacteria in the sponge tissues, as has been carried out for Aplysina cavernicola (Friedrich et al. 1999).

It is interesting to note that, as a group, the 6 strains of Amphimedon viridis-associated bacteria were resistant to the amphitoxin/halitoxin mixture, as well as to polymixin B (Table 3). The latter is a bactericidal cyclic peptide antibiotic, which acts by binding to the bacterial cytoplasmic membrane. The positively charged peptide ring is thought to bind electrostatically with the anionic phosphate head groups of the membrane, thus affecting the normal organization of the membrane and altering its permeability characteristics (Franklin \& Snow 1981). The fact that the amphitoxin/ halitoxin mixture was also positively charged, and all isolated $A$. viridis-associated bacteria were resistant to it as well as to polymixin B, leads us to suggest that the amphitoxin/halitoxin mixture mimics the mode of action of this class of antibiotics. Furthermore, it also leads us to hypothesize that these resistant bacteria probably have special membrane properties that interfere with the antibiotic action. Further investigation is still required in order to determine the mode of action of amphitoxin and halitoxin and the mode of resistance of $A$. viridis-associated bacteria to these highly potent antibiotics.

Acknowledgements. We thank the staff of the Inter University Institute of Marine Biology at Eilat for their hospitality and facilities. We thank A. Rudi for the NMR work, A. Gottlieb, N. Avni and R. Gottlieb for laboratory assistance, and M. Rosenfeld for statistical advice. A. Kushmaro is acknowledged for isolating several of the bacterial strains used in this study. We thank F. Skandarani for his help with the electron microscopy studies, and N. Paz for editorial assistance. The helpful comments of 4 anonymous reviewers are greatly acknowledged. This research was supported by a grant from Israel Ministry of Science, Culture and Sports.

\section{LITERATURE CITED}

Albrizio S, Ciminiello P, Fattorusso E, Magno S, Pawlik JR (1995) Amphitoxin, a new high molecular weight antifeedant pyridinium salt from the Caribbean sponge Amphimedon compressa. J Nat Prod 58:647-652

Amade P, Charroin C, Baby C, Vacelet J (1987) Antimicrobial activities of marine sponges from the Mediterranean Sea. Mar Biol 94:271-275

Antonius A (1985) Black band disease infection experiments on hexacorals and octocorals. Proc 5th Int Coral Reef Symp Tahiti 6:155-160

Austin B (1988) Marine microbiology. Cambridge University Press, New York

Becerro MA, Lopez NI, Turon X, Uriz MJ (1994) Antimicrobial activity and surface bacterial film in marine sponges. J Exp Mar Biol Ecol 179:195-205

Bergquist PR (1978) Sponges. University of California Press, Berkeley

Bergquist PR, Bedford JJ (1978) The incidence of antibacterial activity in marine Demospongiae; systematic and geographic considerations. Mar Biol 46:216-221

Berlinck RGS, Ogawa CA, Almeida AMP, Sanchez MAA, Malpezzi ELA, Costa LV, Hajdu E, de Freitas JC (1996) Chemical and pharmacological characterization of halitoxin from Amphimedon viridis (Porifera) from the southeastern Brazilian coast. Comp Biochem Physiol C 115: 155-163

Bewley CA, Holland ND, Faulkner DJ (1996) Two classes of metabolites from Theonella swinhoei are localized in distinct populations of bacterial symbionts. Experientia 52: 716-722

Buck JD (1982) Nonstaining (KOH) method for determination of Gram reactions of marine bacteria. Appl Environ Microbiol 44:992-993

De Silva ED, Scheuer PJ (1980) Manoalide, an antibiotic sesterterpenoid from the marine sponge Luffariella variavilis (Polejaeff). Tet Lett 21:1611-1614

Ducklow WH (1990) The biomass, production and fate of bacteria in coral reefs. In: Dubinsky Z (ed) Ecosystems of the world: coral reefs. Elsevier, New York, p 265-289

Dworjanyn SA, De Nys R, Steinberg PD (1999) Localisation and surface quantification of secondary metabolites in the red alga Delisea pulchra. Mar Biol 133:727-736

Edmunds PJ (1991) Extent and effect of Black Band Disease on a Caribbean reef. Coral Reefs 10:161-165

Faulkner DJ (2000) Marine natural products. Nat Prod Rep $17: 7-55$

Franklin TJ, Snow GA (1981) Biochemistry of antimicrobial action. Chapman and Hall, London

Friedrich $A B$, Merkert $H$, Fendert $T$, Hacker J, Proksch $P$, Hentschel U (1999) Microbial diversity in the marine sponge Aplysina cavernicola (formerly Verongia cavernicola) analyzed by fluorescence in situ hybridization (FISH). Mar Biol 134:461-470

Hay ME (1996) Marine chemical ecology: what's known and what's next? J Exp Mar Biol Ecol 200:103-134

Higgs MD, Faulkner DJ (1978) Plakortin, an antibiotic from Plakortis halichondroides. J Org Chem 43:3454-3457

Hodgson G (1990) Tetracycline reduces sedimentation damage to corals. Mar Biol 104:493-496

Holt JG, Krieg NR, Sneath PHA, Staley JT, Williams ST (1994) Bergey's Manual ${ }^{\circledR}$ of determinative bacteriology, 9th edn. Williams \& Wilkins, Baltimore

Jenkins KM, Jensen PR, Fenical W (1998) Bioassay with marine organisms: Part II. Marine microbial chemical ecology. In: Haynes K, Millar JC (eds) Methods in chemical ecology. 
Chapman and Hall, New York, p 1-32

Jensen PR, Harvell CD, Wirtz K, Fenical W (1996) Antimicrobial activity of extracts of Caribbean gorgonian corals. Mar Biol 125:411-419

Kelman D, Kushmaro A, Loya Y, Kashman Y, Benayahu Y (1998) Antimicrobial activity of a Red Sea soft coral, Parerythropodium fulvum fulvum: reproductive and developmental considerations. Mar Ecol Prog Ser 169:87-95

Kim K (1994) Antimicrobial activity in gorgonian corals (Coelenterata, Octocorallia). Coral Reefs 13:75-80

Kushmaro A, Loya Y, Fine M, Rosenberg E (1996) Bacterial infection and coral bleaching. Nature 380:396

Kushmaro A, Rosenberg E, Fine M, Loya Y (1997) Bleaching of the coral Oculina patagonica by Vibrio AK-1. Mar Ecol Prog Ser 147:159-165

Maximilien R, de Nys R, Holmström C, Gram L, Givskov M, Crass K, Kjelleberg S, Steinberg PD (1998) Chemical mediation of bacterial surface colonisation by secondary metabolites from the red alga Delisea pulchra. Aquat Microb Ecol 15:233-246

Mitchell R, Chet I (1975) Bacterial attack of corals in polluted seawater. Microb Ecol 2:227-233

Newbold RW, Jensen PR, Fenical W, Pawlik JR (1999) Antimicrobial activity of Caribbean sponge extracts. Aquat Microb Ecol 19:279-284

Rublee AP, Lasker RH, Gottfriend M, Roman RM (1980) Production and bacterial colonization of mucus from the soft

Editorial responsibility: Fereidoun Rassoulzadegan, Villefranche-sur-Mer, France coral Briarium asbestinum. Bull Mar Sci 30:888-893

Schmitt TM, Hay ME, Lindquist N (1995) Constraints on chemically mediated coevolution-multiple functions for seaweed secondary metabolites. Ecology 76:107-123

Schmitz FJ, Hollenbeak KH, Campbell DC (1978) Marine natural products: halitoxin, toxic complex of several marine sponges of the genus Haliclona. J Org Chem 43: 3916-3922

Slattery M, McClintock JB, Heine JN (1995) Chemical defenses in Antarctic soft corals: evidence for antifouling compounds. J Exp Mar Biol Ecol 190:61-77

Sokal RR, Rohlf FJ (1995) Biometry. The principles and practice of statistics in biological research, 3rd edn. WH Freeman and $\mathrm{Co}$, New York

Uriz MJ, Turon X, Galera J, Tur JM (1996) New light on the cell location of avarol within the sponge Dysidea avara (Dendroceratida). Cell Tissue Res 285:519-527

Wahl M, Jensen PR, Fenical W (1994) Chemical control of bacterial epibiosis on ascidians. Mar Ecol Prog Ser 110: 45-57

Wallace RW (1997) Drugs from the sea: harvesting the results of aeons of chemical evolution. Molec Med Today 3: 291-295

Walls JT, Ritz DA, Blackman AJ (1993) Fouling, surface bacteria and antibacterial agents of four bryozoan species found in Tasmania, Australia. J Exp Mar Biol Ecol 169: $1-13$

Submitted: September 20, 2000; Accepted: January 12, 2001 Proofs received from author(s): March 20, 2001 